University of Nebraska - Lincoln

DigitalCommons@University of Nebraska - Lincoln

Mammalogy Papers: University of Nebraska

State Museum

Museum, University of Nebraska State

June 1966

Records of Bats from Western North Dakota

J. Knox Jones Jr.

University of Kansas, Lawrence

Hugh H. Genoways

University of Kansas, Lawrence, h.h.genoways@gmail.com

Follow this and additional works at: https://digitalcommons.unl.edu/museummammalogy

Part of the Zoology Commons

Knox Jones, J. Jr. and Genoways, Hugh H., "Records of Bats from Western North Dakota" (1966).

Mammalogy Papers: University of Nebraska State Museum. 57.

https://digitalcommons.unl.edu/museummammalogy/57

This Article is brought to you for free and open access by the Museum, University of Nebraska State at DigitalCommons@University of Nebraska - Lincoln. It has been accepted for inclusion in Mammalogy Papers: University of Nebraska State Museum by an authorized administrator of DigitalCommons@University of Nebraska Lincoln. 


\title{
Records of Bats from Western North Dakota
}

\author{
J. KNOX JONES, JR. and HUGH H. GENOWAYS
}

From June 16 to 19 and again from June 24 to 29, 1965, a field party from the Museum of Natural History of The University of Kansas collected mammals along the Little Missouri River at a place $1 \mathrm{mi} . \mathrm{S}$ and 1 mi. W Medora, Billings Co., North Dakota. Among the specimens collected were representatives of five kinds of bats, including one species unreported from North Dakota, a subspecies unrecorded from there, and two species known previously from the state by a single specimen each.

We camped at an abandoned farm in the Little Missouri Valley at a point where the valley is approximately one mile wide and lies entirely to the east of the river. Rugged cliffs and bluffs, in which bats may have found daytime retreats, rise abruptly on the west side to a height of 100 feet or more above the stream. A deciduous riparian association consisting of scattered trees (mostly cottonwoods) occupies an area 100 yards or so wide adjacent to the river. All bats taken were shot at dusk as they flew among these trees. Bats were seen in numbers there only when it was windy, suggesting that they foraged more in open areas on calm evenings.

In the accounts that follow, measurements are given in millimeters and weights are recorded in grams. A grant (GE-7739) from the Na. tional Science Foundation made possible student participation in field work.

Myotis evotis evotis H. Allen, 1864.-A male long-eared myotis, which weighed 6.9 and had testes that measured 5, was shot on June 26. This specimen (KU 100737) is the second to be reported from North Dakota; the earlier record is from Beaver Creek, $4 \mathrm{mi}$. W Grinnell, Williams County (Bailey, 1927:217).

Myotis leibii ciliolabrum (Merriam, 1886).-This saxicolous species seemingly is the commonest member of the genus at the place we collected. Six females (KU 100763-68) were obtained. Two of these were pregnant, each carrying a single embryo that measured 9 (June 17) and 11 (June 24) in crown-rump length. The pregnant female taken on June 24 was in an early stage of molt. The four non-pregnant females averaged $5.2(4.5-5.5)$ in weight.

Transactions of the Kansas Academy of Science, Vol. 69, No. 1, 1966. Published June 15, 1966. 
The specimens herein reported provide the second locality of record for $M$. leibii in North Dakota. The species was known previously by a single specimen from along the Little Missouri at a place $8 \mathrm{mi}$. N and $71 / 2$ mi. W Amidon, Slope County (Jones and Stanley, 1962:263), because Bailey's (1927:216) account of this bat from North Dakota actually applies to Myotis keenii (see Miller and Allen, 1928:168).

We follow Glass and Baker (1965) in the use of the specific name leibii for this species, formerly known as Myotis subulatus, although we fail to appreciate why Glass and Baker listed Harrison Allen (1894) as the author of the subspecific name ciliolabrum. Merriam's (1886) original description of Vespertilio ciliolabrum clearly is the oldest valid name for this bat.

Myotis lucifugus carissima Thomas, 1904.-Three males (KU 100741-43) were shot on the evenings of June 17 and 18. The weight of the three varied from 7.1 to 8.5 ; testes from each of two specimens measured 4. Our specimens are intergrades between M. l. carissima and M. l. lucifugus and are referred to the former because they resemble carissima in cranial features. In color, our specimens are intermediate between typical representatives of the two subspecies. Bats of this species from elsewhere in western North Dakota also are intergrades between carissima and lucifugus. Examination of the pertinent material in the U. S. National Museum leads us to follow Bailey (1927:215), rather than Miller and Allen (1928:46), in referring to carissima the specimens from Cannon Ball, Goodall, and $8 \mathrm{mi}$. N Towner. A male from $5 \mathrm{mi}$. W Minot, Ward County (KU 103114), also is assigned to this subspecies.

On the basis of published records (see Miller and Allen, 1928:69, and Hall and Kelson, 1959:163) the bat presently known as Myotis yumanensis, a species closely allied to $M$. lucifugus, might be expected to occur in extreme western North Dakota. However, Long (1965:529) has shown that the one specimen reported from Wyoming as yumanensis actually is lucifugus, and our examination of the specimen reported previously from Powderville, Montana, shows it also to be lucifugus. Evidently, M. yumanensis is limited in the northern part of its range to the region west of the Continental Divide.

Myotis volans interior Miller, 1914.-A male (KU 100780) weighing 6.8 and having testes that measured 4 was taken on June 28 . It provides the first North Dakotan record of this species, extending the known geographic distribution approximately 190 miles north-northeastward from $1 / 2$ mi. E Buckhorn, Weston Co., Wyoming (Long, 1965:531). 
Eptesicus fuscus pallidus Young, 1908.-The big brown bat was the most abundant chiropteran species collected along the Little Missouri. Fifteen specimens (KU 100806-20) were obtained, only one of which, a non-pregnant female taken on June 17, had begun the annual molt. Four of eight females were pregnant; one carried two embryos (June 17) that measured 12 in crown-rump length, whereas the others each contained a single embryo that measured 13 (June 17), 11, and 21 (both June 24). Testes of six adult males averaged 6.6 (4-9) in length.

The subspecies $E$. f. pallidus has not been reported previously from North Dakota although specimens examined in the U. S. National Museum from Cannon Ball, Sioux County, and from $4 \mathrm{mi}$. W Grinnell and Ft. Union, Williams County, all listed by Bailey (1927:210) as E. f. fuscus, are referable to pallidus.

\section{Literature Cited}

AlleN, $\mathrm{H}$.

1894. A monograph of the bats of North America. Bull. U. S. Nat. Mus., 43:ix + 1-198, 38 pls., March 14.

BAILEY, V.

1927. A biological survey of North Dakota. N. Amer. Fauna, 49:vi + 1-226, 21 pls., 8 figs., January 8.

Glass, B. P., and R. J. BAKer

1965. Vespertilio subulatus Say, 1823: proposed suppression under the plenary powers (Mammalia, Chiroptera). Bull. Zool. Nomenclature, 22:204205, August.

HALl, E. R., and K. R. KelsoN

1959. The mammals of North America. Ronald Press, New York, 1:xxx + $1-546+79$, illustrated, March 31 .

Jones, J. K., JR., and W. C. STANLEY

1962. Myotis subulatus in North Dakota. Jour. Mamm., 43:263, May 29.

LoNG, C. A.

1965. The mammals of Wyoming. Univ. Kansas Publ., Mus. Nat. Hist., 14:493-758, 82 figs., July 6.

MERRIAM, C. H.

1886. Description of a new species of bat from the western United States. Proc. Biol. Soc. Washington, 4:1-4, December 17.

Miller, G. S., JR., and G. M. Allen

1928. The American bats of the genera Myotis and Pizonyx. Bull. U. S. Nat. Mus., 144:viii + 1-218, 1 pl., 1 fig., 13 maps, May 25.

-Museum of Natural History, The University of Kansas, Lawrence Transmitted February 22, 1966 